\title{
PENELITIAN TINDAKAN KELAS \\ THINK PAIR SHARE UNTUK MATA PELAJARAN AKUNTANSI
}

\author{
Budi Mulyati $^{1)}$, Kiki Ernawati ${ }^{2)}$ \\ Universitas Banten Jaya \\ Serang, Indonesia \\ budimulyati@unbaja.ac.id ${ }^{1)}$,ernawatikiko@gmail.com ${ }^{2)}$
}

\begin{abstract}
The study was conducted to improve the result study in Accounting Subject used think pair share in SMK AlInsan Cilegon. The study used classroom action research with two cycles. Each cycle encompased planning, implementing, observing and reflecting. The subject of the study were 48 students in class ten and teacher as a collaborator. The result showed that using think pair share could improve the results study up to $87,5 \%$ in second cycle.
\end{abstract}

Keywords: Think Pair Share, Accounting Subject

\section{PENDAHULUAN}

Pembelajaran merupakan proses belajar yang dilakukan secara dua arah, baik oleh guru maupun peserta didik. Dalam kurikulum 2013, peserta didik merupakan subjek utama dalam pembelajaran karena peserta didik belajar secara aktif, tidak lagi menunggu guru untuk memberikan materi pembelajaran namun peserta didik memiliki inisiatif untuk mencari sendiri materi apa yang mereka butuhkan. Sehingga dapat dikatakan dalam pembelajaran peserta didik menjadi subjek utama terselenggaranya pembelajaran yang aktif.

$$
\text { Berlangsungnya proses }
$$

pembelajaran yang demikian, akan menuntut guru untuk mampu membuat perencanaan pembelajaran yang mampu menumbuhkan semangat dan motivasi peserta didik untuk melakukan aktivitas belajar secara mandiri maupun kelompok. Walaupun peserta didik ditekankan untuk mampu belajar secara aktif dan mandiri, namun bukan berarti guru menjadi pihak yang pasif. Guru memiliki peran yang sangat penting sebagai subjek yang akan mengarahkan tentang tujuan dari kegiatan belajar yang dilakukan oleh peserta didik. Guru juga akan memberikan penilaian terhadap hasil belajar yang telah dilakukan peserta didik serta membantu memberi pemaknaan terhadap hasil belajar peserta didik. 
Berdasarkan kegiatan observasi yang sudah dilakukan di SMK Al- Insan Cilegon kelas X Ak pada bulan April di tahun 2017, diperoleh informasi bahwa untuk mata pelajaran akuntansi, terdapat sebanyak $42 \%$ peserta didik (dari 48 peserta didik) yang tidak berhasil memperoleh nilai minimal dalam kegiatan ujian tengah semester. Hasil perolehan nilai ujian tengah semester tersebut akan menjadi bahan evaluasi bagi guru untuk menganalisis kekurangan yang muncul saat proses pembelajaran berlangsung. Beberapa hasil analisis menyebutkan bahwa rendahnya perolehan nilai ketuntasan belajar untuk mata pelajaran akuntansi dikarenakan peserta didik tidak aktif saat proses pembelajaran berlangsung. Peserta didik cenderung hanya mendengar apa yang disampaikan guru dan sedikit sekali terjadi interaksi tanya jawab, terutama saat terjadi diskusi.

Hal lain yang ditemui peneliti saat observasi yakni dalam penggunaan cara mengajar yang dilakukan guru yang masih sering menggunakan cara mengajar yang kurang bervariasi. Guru mengandalkan materi yang kemudian disampaikan kepada peserta didik di kelas. Peran guru menjadi pusat belajar sedangkan peserta didik lebih banyak mendengarkan guru. Walaupun cara demikian dapat dilakukan, namun untuk menjaga konsentrasi peserta didik dalam waktu yang lama akan menjadi sulit. Sehingga banyak diantara peserta didik yang terlihat tidak bersemangat saat proses pembelajaran berlangsung.

Berdasarkan Widiaswara, (2018: 80), guru memiliki peran yang sangat penting dalam proses pembelajaran, setidaknya terdapat tiga peran guru dalam kelas, diantaranya: 1). guru sebagai pengajar, 2). guru sebagai pendidik dan 3). guru sebagai pemimpin. Berdasarkan peran- peran yang dimilki oleh guru tersebut, guru akan mampu mengelola kelas dengan baik. Sebagai pengajar guru harus mampu menyampaikan materi sesuai dengan silabus, dengan demikian dapat dikatakan guru menjadi sumber informasi bagi peserta didik di kelas tentang kemampuan atau kompetensi apa saja yang harus dikuasai peserta didik. Guru sebagai pendidik memiliki peran tidak hanya dalam hal penyampaian materi namun sekaligus harus mampu membentuk peserta didik memiliki karakter dan ahlak yang baik. Kemudian peran guru sebagai pemimpin bermakna bahwa guru harus mampu mengelola, mengatur serta mengendalikan kelas dari awal pembelajaran hingga akhir. Dengan demikian kondisi dan suasana kelas selama proses pembelajaran dapat selalu kondusif. Sehingga dapat disimpulkan bahwa peran- 
peran yang dimiliki oleh guru selayaknya dimaknai dengan baik, karena hal tersebut akan bermanfaat bagi guru agar dapat menciptakan proses pembelajaran yang aktif dan kreatif. Salah satu cara yang dapat digunakan guru untuk mengelola kelas dengan baik yakni guru harus memperhatikan strategi pengelolaan di kelas.

Berdasarkan Widiaswara (2018: 109), adanya penggunaan model pembelajaran yang bervariasi dapat membantu guru untuk menciptakan pembelajaran yang menyenangkan bagi peserta didik. Beberapa model pembelajaran yang dapat digunakan diantaranya:

a. Active Debate

b. Auditory, Intelectually, Repetition

c. Bamboo Dancing

d. Contexctual Teaching and Learning

e. Cooperative Learning

f. Creative Problem Solving

g. Mind Mapping

h. Problem Based Learning

i. Role Playing

j. Make a Match

k. Snowball Throwing

(Widiaswara, 2018: 110).

Dari beberapa model pembelajaran tersebut, model pembelajaran Cooperative Learning dapat digunakan oleh guru di kelas.. Model pembelajaran ini banyak melibatkan peserta didik sebagai subjek utama dalam proses pembelajaran. Dalam model pembelajaran kooperatif peserta didik dapat saling membantu untuk memahami suatu materi pelajaran (Slavin, 2005:4). Hal ini dapat dipahami karena terdapat beberapa alasan mengapa model pembelajaran kooperatif dapat meningkatkan prestasi belajar peserta didik, diantaranya adanya peningkatan hubungan baik diantara peserta didik, terdapat penerimaan terhadap sesama teman di kelas serta adanya peningkatan harga diri peserta didik, (Slavin, 2005:5).

Beberapa alasan tersebut dapat terjadi karena dalam model pembelajaran kooperatif peserta didik secara sadar paham bahwa mereka harus belajar untuk bisa berpikir. Peserta didik harus bisa menyelesaikan masalah sekaligus dapat mengimplementasikan pengetahuannya ke dalam dunia nyata. (Slavin, 2005:5).

Pembelajaran kooperatif dinilai mampu mengembangkan beberapa hal tersebut, karena dalam pembelajaran kooperatif keberagaman yang terdapat pada kelompok peserta didik akan menjadi kekuatan untuk dapat mengembangkan segala kemungkinan pengembangan belajar yang sedang dilakukannya. Semakin banyak informasi dan pengalaman yang dimiliki peserta didik, maka akan semakin memperkaya pengetahuan dan pemahaman peserta didik terhadap suatu materi pelajaran. 
Namun demikian, terdapat beberapa langkah yang harus dilakukan oleh guru untuk menerapkan model pembelajaran kooperatif seperti terlihat pada tabel 1 berikut ini;

Tabel 1. Langkah Pembelajaran Kooperatif

\begin{tabular}{|c|c|}
\hline Langkah & Keterangan \\
\hline Langkah 1 & $\begin{array}{l}\text { Memilih metode, teknik } \\
\text { dan struktur } \\
\text { pembelajaran kooperatif }\end{array}$ \\
\hline Langkah 2 & Menata Ruang kelas \\
\hline Langkah 3 & $\begin{array}{l}\text { Merangking peserta } \\
\text { didik }\end{array}$ \\
\hline Langkah 4 & $\begin{array}{l}\text { Menentukan jumlah } \\
\text { kelompok }\end{array}$ \\
\hline Langkah 5 & $\begin{array}{l}\text { Membentuk kelompok- } \\
\text { kelompok }\end{array}$ \\
\hline Langkah 6 & $\begin{array}{ll}\text { Merancang } & \text { team } \\
\text { buliding untuk setiap } \\
\text { kelompok }\end{array}$ \\
\hline Langkah 7 & $\begin{array}{l}\text { Mempresentasikan } \\
\text { materi pembelajaran }\end{array}$ \\
\hline Langkah 8 & $\begin{array}{l}\text { Membagikan lembar } \\
\text { kerja siswa }\end{array}$ \\
\hline Langkah 9 & $\begin{array}{l}\text { Menugaskan peserta } \\
\text { didik mengerjakan } \\
\text { tugas secara mandiri }\end{array}$ \\
\hline Langkah 10 & $\begin{array}{l}\text { Menilai dan menskor } \\
\text { hasil tuga speserta didik }\end{array}$ \\
\hline Langkah 11 & $\begin{array}{l}\text { Memberi penghargaan } \\
\text { pada kelompok }\end{array}$ \\
\hline Langkah 12 & $\begin{array}{l}\text { Mengevaluasi perilaku } \\
\text { anggota kelompok }\end{array}$ \\
\hline
\end{tabular}

Sumber: Huda (2015: 163).

Berdasarkan tabel 1, terlihat bahwa terdapat serangkaian tindakan yang harus dilakukan oleh guru untuk mengelola pembelajaran di kelas menggunakan model Cooperatif Learning. Mulai dari memilih teknik atau struktur pembelajaran kooperatif hingga proses evaluasi baik dalam hal perolehan nilai maupun aktivitas perilaku dan tindakan peserta didik.

Terdapat berbagai variasi kelompok penggunaan model pembelajaran kooperatif, yakni kelompok berpasangan, kelompok bertiga, kelompok berempat dan kelompok berlima, (Anita Lie dalam Widarto, 2017: 107). Setiap variasi kelompok memiliki peruntukkannya masing- masing sesuai dengan tema materi yang akan diberikan oleh guru.

Untuk mata pelajaran akuntansi, penggunaan kelompok berpasangan dapat membuat proses pembelajaran menjadi lebih mudah. Karena dilihat dari jumlah anggota kelompoknya yang hanya dua orang membuat proses belajar diksusi menjadi lebih fokus. Hal ini dimungkinkan karena mata pelajaran akuntansi memerlukan fokus yang lebih lama karena berkaitan dengan konsep sekaligus penghitungan angka-angka. Sehingga dengan jumlah anggota kelompok yang tidak terlalu banyak memungkinkan para anggota kelompoknya untuk dapat berdiskusi secara lebih fokus. Dalam kelompok berpasangan setiap anggota 
kelompoknya dapat saling memberi masukan sehingga tercipta kegiatan diskusi secara aktif. Salah satu model kelompok berpasangan yang dapat digunakan yakni model think pair share.

Efektifitas penggunaan model think pair share diungkapkan oleh Kothiyal, dkk (2013: 137) yang menyatakan bahwa model think pair share efektif dapat meningkatkan komitmen peserta didik hingga $83 \%$. "... found that $83 \%$ of students on average were fully or mostly engaged".

Beberapa ciri yang membuat model pembelajaran Think Pair Share dapat efektif diterapkan di kelas diantaranya:

a. Memungkinkan peserta didik untuk bekerja sendiri sekaligus bekerja sama dengan orang lain

b. Mengoptimalkan partisipasi peserta didik

c. Dapat diterapkan untuk semua mata pelajaran.

(Huda, 2015 136).

\section{METODE PENELITIAN}

Penelitian ini dilakukan di SMK Al- Insan Cilegon kelas X Ak. Penelitian ini dilakukan selama bulan April 2017. Penelitian ini menggunakan penelitian tindakan kelas yang terdiri dari dua siklus. Setiap siklus memiliki empat tahap diantaranya tahap perencanaan, pelaksanaan, observasi, dan refleksi. Dalam penelitian ini peneliti bersama guru bekerjasama menjadi tim kolaborasi. Bentuk kolaborasi yang terjadi dalam bentuk:

a. Peneliti berperan dalam bentuk penyiapan bahan dan perangkat belajar dan sebagai observer

b. Guru berperan sebagai pelaksana yang mengimplementasikan perangkat pembelajaran yang telah dibuat.

c. Peneliti dan guru melakukan diskusi tentang permasalahan yang ditemui di kelas dan sekolah kemudian berdiskusi tentang rencana tindak lanjut.

Materi atau subjek pelajaran yang diberikan kepada peserta didik yakni tentang proses pencatan jurnal ke dalam buku besar. Adapun tahapan pelaksanaan penelitian tindakan kelas dengan menggunakan model think pair share dapat dijelaskan pada tabel berikut ini:

Tabel 2. Tahapan Penelitian

\begin{tabular}{cll}
\hline Siklus & Tahapan & Deksripsi \\
\hline I & Identifikasi & - Mengamati \\
& Masalah & proses \\
& & pembelajaran di \\
& & kelas \\
& & Identifikasi \\
& & permasalahan \\
& & Menyusun \\
& & hipotesis \\
& & permasalahan \\
& & - Melakukan \\
& & penelitian \\
& & \\
&
\end{tabular}




\begin{tabular}{|c|c|c|}
\hline & Perencanaan & $\begin{array}{l}\text { - Membuat } \\
\text { rencana } \\
\text { pembelajaran } \\
\text { (RPP) } \\
\text { menggunakan } \\
\text { think pair share }\end{array}$ \\
\hline & Pelaksanaan & $\begin{array}{l}\text { - Merencanakan } \\
\text { pembelajaran } \\
\text { sesuai RPP } \\
\text { - Melakukan } \\
\text { evaluasi } \\
\text { menggunakan } \\
\text { tes }\end{array}$ \\
\hline & Observasi & $\begin{array}{l}\text { - Melakukan } \\
\text { observasi } \\
\text { menggunakan } \\
\text { lembar } \\
\text { observasi dan } \\
\text { catatan harian }\end{array}$ \\
\hline & Refleksi & $\begin{array}{l}\text { - Melakukan } \\
\text { evaluasi } \\
\text { tindakan yang } \\
\text { telah dilakukan }\end{array}$ \\
\hline II & Perencanaan & $\begin{array}{l}\text { - Identifikasi } \\
\text { masalah } \\
\text { - Membuat RPP } \\
\text { - Menyiapkan } \\
\text { lembar } \\
\text { observasi dan } \\
\text { catatan harian }\end{array}$ \\
\hline & Pelaksanaan & $\begin{array}{l}\text { - Melakukan } \\
\text { tindakan sesuai } \\
\text { dengan RPP } \\
\text { - Membuat } \\
\text { evaluasi } \\
\text { tindakan }\end{array}$ \\
\hline & Observasi & $\begin{array}{l}\text { - Merekam } \\
\text { kegiatan ke } \\
\text { dalam lembar } \\
\text { observasi dan } \\
\text { catatan harian }\end{array}$ \\
\hline & Refleksi & $\begin{array}{l}\text { - Melakukan } \\
\text { evaluasi } \\
\text { tindakan. }\end{array}$ \\
\hline
\end{tabular}

Berdasarkan tabel 2 dapat diketahui bahwa penelitian menggunakan beberapa siklus, dimana siklus akan terus dilanjutkan jika hasil pada siklus ke 2 belum menunjukkan hasil yang diinginkan. Hasil yang diinginkan dalam penelitian ini dinamakan dengan istilah indikator keberhasilan. Indikator keberhasilan pada penelitian ini ditentukan berupa $80 \%$ dari jumlah peserta didik telah memiliki nilai diatas nilai minimal (KKM) sebesar 75 .

Data penelitian dikumpulkan menggunakan teknik tes dan observasi, sehingga instrumen penelitian yang digunakan yakni menggunakan lembar tes dan lembar observasi. Untuk mengolah data hasil penelitian digunakan teknik analisis data deskriptif kuantitatif.

\section{HASIL PENELITIAN DAN PEMBAHASAN}

Hasil Penelitian

Penelitian pada siklus 1 terjadi pada 26 April 2017 dan 03 Mei 2017. Pada tahap perencanaan peneliti menyiapkan rencana pembelajaran berdasarkan hasil diskusi dengan guru. Masing- masing pertemuan dilakukan dalam jangka waktu 2x45 menit. Bentuk skenario menggunakan think pair share terutama terlihat dalam bentuk a). peserta didik diminta untuk memikirkan (think) penyelesaian terhadap kasus/ masalah yang diberikan guru, b). peserta didik 
diminta untuk mengajak satu orang teman kelasnya untuk membentuk kelompok (pair), c). peserta didik bersama teman kelompoknya melakukan diskusi tentang permasalahan dan solusi yang ditemukan oleh masing- masing kelompok kemudian mendiskusikan hasilnya (share).

Pada tahap pelaksanaan, penelitian dilakukan secara partisipatif. Peneliti bertindak sebagai observer sedangkan guru menyampaikan materi berdasarkan perangkat yang disiapkan oleh peneliti dan guru. Pelaksanaan pada siklus I dilakukan sebanyak dua kali pertemuan.

Pada tahap observasi, peneliti menggunakan lembar observasi untuk mencatat aktivitas peserta didik selama proses pembelajaran berlangsung. Lembar observasi yang digunakan merupakan lembar observasi yang dibuat oleh guru dan peneliti. Pada lembar observasi berisi keterangan tentang peran masing- masing peserta didik dalam kelompoknya. Indikatornya berupa kerjasama dengan teman (pair), ketepatan waktu dalam mengerjakan tugas, ketepatan waktu dalam mengumpulkan tugas serta presentasi (share).

Berdasarkan hasil observasi diperoleh informasi bahwa ketuntasan belajar dari 48 peserta didik yang ada di kelas X Ak sebesar 72,91\%. Sedangkan aktivitas peserta didik dinyatakan sebesar $60 \%$.

Pada tahap refleksi peneliti melakukan penilaian terhadap proses pembelajaran yang sudah dilakukan. Secara umum, proses pembelajaran pada siklus I terjadi dengan baik, hal ini ditandai dengan tingginya antusiasme peserta didik. Namun demikian, hasil belajar yang dicapai belum mencapai indikator keberhasilan yang diharapkan. Sehingga peneliti dan guru memutuskan untuk melanjutkan proses pembelajaran ke siklus II.

Beberapa faktor yang dianalisis oleh peneliti dan guru pada tahap refleksi diantaranya:

a. Terdapat beberapa peserta didik yang belum bisa menjalin kerja sama dengan teman kelompoknya

b. Terdapat peserta didik yang bekerja sama dengan anggota kelompok yang lain

c. Peserta belum ada yang berani melakukan presentasi ke depan kelas, sehingga kegiatan presentasi masih dilakukan oleh guru

d. Terdapat banyak peserta didik yang bertanya kepada guru, sehingga guru menjadi sulit membagi waktu ketika terjadi diskusi.

Siklus II dilakukan berdasarkan hasil refleksi dari siklus I. Berdasarkan 
hasil analisis proses pembelajaran di siklus

I, terdapat beberapa penegasan yang menjadi bahan pertimbangan untuk mengembangkan proses pembelajaran di siklus II, diantaranya:

a. Guru menekankan tujuan penggunaan model Think Pair Share selama proses pembelajaran ke depan.

b. Guru memberikan motivasi kepada peserta didik untuk berani mengemukakan pendapat.

c. Guru melakukan penekanan terhadap materi yang penting terlebih sehingga peserta didik akan terbantu ketika menerima materi pengembangan.

Perencanaan pada siklus II dilakukan berdasarkan hasil refleksi pada siklus I. Penyusunan RPP dibuat untuk mengatasi permasalahan pada siklus sebelumnya. Jumlah pertemuan pada siklus II dilakukan sebanyak satu kali pertemuan.

Pelaksanaan pada siklus II dilakukan pada tanggal 09 Mei 2017. Pada siklus II peneliti berperan sebagai guru sekaligus observer. Pada tahap pelaksanaan peneliti mengaplikasikan RPP dengan model Think Pair Share di kelas. Guru memberikan tugas untuk dikerjakan oleh masing- masing kelompok (think) untuk selanjutnya dipresentasikan di depan kelas (Share). Aktivitas selama proses pembelajaran tersebut tetap tercatat di lembar observasi untuk merekam segala peristiwa yang terjadi selama proses pembelajaran berlangsung.

Pada saat observasi di siklus II, peneliti mencatat beberapa perubahan sikap peserta didik. Peserta didik sudah terlihat lebih percaya diri untuk menyajikan hasil diskusi dengan teman kelompoknya sekaligus berani untuk menyampaikan pendapatnya.

Beberapa perubahan yang terrekam saat siklus II diantaranya:

a. Kondisi kelas sudah lebih tertib bila dibandingkan saat siklus I

b. Kondisi kelas yang sudah teratur membuat peserta didik lebih siap menerima pembelajaran.

c. Berdasarkan hasil pengamatan aktivitas peserta didik meningkat menjadi $87,69 \%$.

Bila dapat digambarkan, perbedaan aktivitas peserta didik berdasarkan hasil observasi dapat digambarkan sebagai berikut,

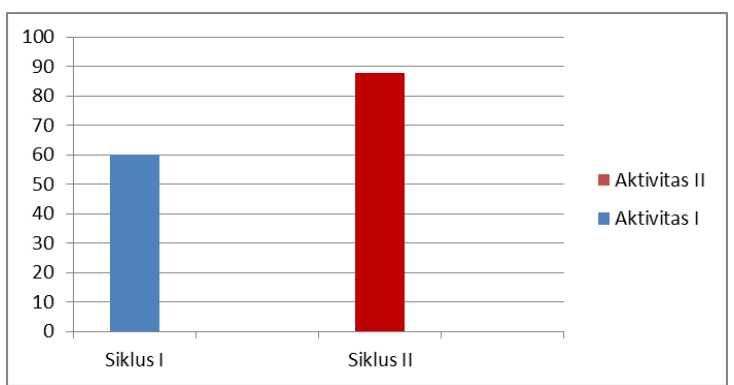

Gb. 1. Perbandingan Aktivitas Peserta Didik Siklus I dan II. 
Pada tahap refleksi di siklus II peneliti melakukan serangkaian analisis terhadap proses pembelajaran dari awal hingga akhir. Pada kegiatan refleksi di siklus II, peneliti menilai proses pembelajaran di siklus II dapat dihentikan, karena berdasarkan hasil belajar dan aktivitas peserta didik sudah mencapai indikator keberhasilan. Hal ini ditandai dengan diperolehnya hasil belajar yang sudah mencapai $87,5 \%$ peserta didik dapat mencapai KKM.

Peneliti menggunakan jenis penelitian tindakan kelas (Classroom Action Research) dengan tujuan untuk memberikan alternatif solusi bagi guru terhadap permasalahan yang dihadapi selama proses pembelajaran.

Berdasarkan hasil observasi awal, diperoleh informasi tentang persentasi ketuntasan belajar peserta didik untuk mata pelajaran akuntansi sebesar $37,05 \%$. Nilai ketuntasan yang masih rendah tersebut salah satunya dimungkinkan karena kurang bervariasinya cara guru dalam menyajikan materi pelajaran.

Setelah kegiatan observasi dan analisis masalah telah dilakukan, peneliti bersama guru melakukan tindakan lanjutan dengan dilakukannya treatment berupa tindakan kelas melalui implementasi penggunaan model pembelajaran Think
Pair Share yang dilakukan sebanyak dua siklus.

Berdasarkan hasil refleksi pada siklus I, terjadi peningkatan nilai ketuntasan belajar peserta didik sebesar 72,91\%. Peneliti bersama guru menganalisis bahwa peningkatan nilai ketuntasan belajar tersebut tejadi disebabkan karena adanya keterlibatan peserta didik secara lebih aktif selama proses pembelajaran. Guru membuat kelompok secara berpasangan yang menuntut peserta didik untuk dapat berpikir secara aktif melalui diskusi dengan masing- masing kelompoknya. Peserta didik menerima proses pembelajaran yang berbeda dari yang biasa diterima.

Sepanjang diskusi dengan kelompoknya, peserta didik berlatih untuk mencari solusi atas tugas yang diberikan oleh guru. Dengan aktivitas yang demikian dapat menumbuhkan kebermaknaan pada diri peserta didik selama proses pembelajaran. Hal tersebut yang kemudian membuat nilai ketuntasan belajar peserta didik menjadi meningkat. Aktivitas selama proses pembelajaran terekam dalam lembar observasi dimana peneliti mencatat setiap komponen yang diamati memiliki nilai yang relatif baik. Berdasarkan hasil analisis terhadap lembar observasi, 
persentase keaktifan peserta didik pada siklus I mencapai $60 \%$.

Walaupun demikian, siklus I dilanjutkan ke siklus II, karena peningkatan yang terjadi pada siklus I belum memenuhi target keberhasilan yang telah ditetapkan oleh peneliti.

Berdasarkan hasil refleksi pada siklus II, nilai ketuntasan hasil belajar peserta didik naik menjadi sebesar 87,5\%. Nilai tersebut dapat dimaknai bahwa dari 48 peserta didik 42 diantaranya telah berhasil memperoleh nilai diatas nilai minimum (KKM), sedangkan sisanya sebanyak enam orang belum memenuhi nilai minimal. Perbedaan nilai ketuntasan saat siklus I dan II dapat diilustrasikan pada gambar berikut ini;

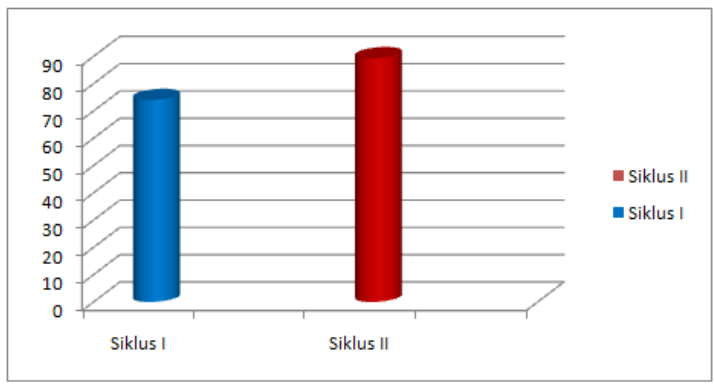

\section{Gb. 2. Perbedaan hasil ketuntasan belajar Siklus I dan II}

Dengan sudah mulai terbiasanya belajar menggunakan model Think Pair Share, akivitas peserta didik selama proses pembelajaran menjadi semakin aktif. Berdasarkan catatan pada lembar observasi, hasil analisis menunjukkan peningkatan aktivitas peserta didik sebesar $87,69 \%$.

Berdasarkan target keberhasilan penelitian, nilai ketuntasan tersebut sudah memenuhi indikator keberhasilan yakni $80 \%$ dari 48 peserta didik memiliki nilai diatas nilai KKM. Dengan demikian, penelitian tidak dilanjutkan ke siklus III.

Peneliti dan guru melaukan refleksi tentang faktor atau hal- hal apa saja yang dapat membuat implementasi model Think Pair Share berhasil dilakukan di kelas. Beberapa faktor tersebut diantaranya;

a. Peserta didik memahami dengan baik tentang tujuan yang akan dicapai selama proses pembelajaran berlangsung. Dengan adanya pemahaman tujuan, maka peserta didik memiliki motivasi untuk mencapai tujuan tersebut.

b. Peserta didik mulai terbiasa dengan penggunaan model pembelajaran Think Pair Share di kelas. Peserta didik sudah memahami tindakan apa saja yang harus dilakukan selama proses pembelajaran terjadi. Mulai dari proses diskusi hingga dilakukannya presentasi hasil belajar dari masing- masing kelompok.

c. Terjadi kompetisi yang positif diantara kelompok. Masing- masing kelompok berusaha untuk menjadi yang terbaik sekaligus membantu kelompok lainnya 
yang dinilai masih kurang. Sehingga diskusi yang terjadi tidak hanya terjadi di dalam kelompoknya namun dengan kelompok- kelompok yang lain.

\section{KESIMPULAN DAN SARAN}

\author{
Beberapa simpulan yang dapat \\ penulis uraikan berdasarkan hasil \\ penelitian diantaranya:
}

a. Model pembelajaran Think Pair Share dapat meningkatkan nilai ketuntasan belajar peserta didik. Berdasarkan hasil analisis, nilai ketuntasan belajar pada siklus I mencapai $72,91 \%$ dan pada siklus II mencapai nilai ketuntasan $87,5 \%$.

b. Aktivitas saat proses pembelajaran menunjukkan peserta didik terlibat secara aktif. Berdasarkan pada hasil analisis lembar observasi, aktivitas peserta didik di siklus I mencapai angka $60 \%$. Sedangkan pada siklus II meningkat menjadi $87,69 \%$.

Beberapa saran yang dapat disampaikan berdasarkan hasil penelitian diantaranya:

a. Pengajar atau guru dapat menggunakan model pembelajaran kooperatif yang lain untuk memberi variasi pembelajaran di kelas.

b. Pengajar atau guru dapat meningkatkan indikator keberhasilan dalam penelitian tindakan kelas sebagai upaya untuk meningkatkan kualitas proses pembelajaran di kelas.

c. Pengajar atau guru dapat mengajak guru dari kelas atau sekolah lain untuk berkolaborasi menerapkan model pembelajaran kooperatif agar dapat memperkaya muatan materi dan proses pembelajaran yang akan di sampaikan di kelas.

\section{DAFTAR PUSTAKA}

Huda, Miftahul. (2015). Cooperative Learning, Metode, Teknik, Struktur dan Model Terapan. Yogyakarta: Pustaka Pelajar

Kothiyal, Aditi dkk. (2013). Proceeding of the ninth annual international ACM Conference on International Computing and Education. 2013. Pg: 137-144. Effect of Think-PairShare in a Large CS1 Class: $83 \%$ Sustained Engagement. San Diego San California.

Slavin, Robert. E. (2005). Cooperatif Learning, Teori, Riset dan Praktik. Terj Narulita Nusron. Bandung: Nusa Media.

Widarto. (2017). Model Pembelajaran Cooperative Learning on Project Work. Yogyakarta: Pustaka Pelajar.

Widiasworo, Erwin. (2018). Cerdas Pengelolaan Kelas. Yogyakarta: Diva Press. 